Maciej Urbanowski

\title{
„Śmierć Romka” (poznański Czerwiec w prozie Janusza Krasińskiego)
}

1.

Pięcioczęściowy cykl powieściowy Janusza Krasińskiego z całą pewnością należy do najważniejszych osiągnięć polskiej prozy po 1989 r. Pentalogia, na którą - przypomnę - składają się wydawane w latach 1992-2015 tomy Na stracenie (1992), Twarza do ściany (1996), Niemoc (1999), Przed agonia (2005) oraz opublikowany już po tragicznej śmierci autora Przełom (2015), zdobyła uznanie krytyki, a poszczególne części cyklu wyróżniano między innymi Nagrodą im. Andrzeja Kijowskiego i Nagrodą Literacką im. Józefa Mackiewicza. O oryginalności dzieła Krasińskiego współdecydowały tematyka oraz oryginalna forma literacka [Burek 2001; Urbanowski 2007; Heck 2008; Burek 2011].

Czytelnik śledzi dramatyczne losy Szymona Bolesty, który jako siedemnastolatek zostaje w $1947 \mathrm{r}$. aresztowany przez UB pod sfingowanym, absurdalnym zarzutem szpiegostwa na rzecz Zachodu i skazany na karę piętnastu lat więzienia. W ten sposób niedawny więzień Oświęcimia i Dachau staje się ofiarą komunizmu i trafia do „kolonii karnych” - Mokotowa, Rawicza i Wronek. O tym opowiadają dwa pierwsze tomy cyklu. W następnych widzimy Bolestę już na wolności, jak szuka swego miejsca 
w niby-Polsce Gomułki, Gierka i Jaruzelskiego. Zostaje pisarzem i chcąc nie chcąc staje się częścią systemu. Cały czas opiera się mu wewnętrznie, próbuje ocalić „okruch własnej duszy” i dojrzewa do napisania dzieła o swym „niecenzuralnym życiorysie” [Krasiński 2015: 440], o tragicznych doświadczeniach z komunistycznych więzień i o ofiarach czerwonego totalizmu.

Bez wątpienia najlepsze są dwa początkowe tomy cyklu. Decyduje o tym sam temat - właściwie nieprzedstawiony w polskiej literaturze', ale też perspektywa, z jakiej o nim się mówi, perspektywa człowieka bardzo młodego, niewinnego, wrażliwego, jakoś naiwnego, a zarazem już skrzywdzonego przez hitleryzm, co pozwala mu wyraźniej dostrzec podobieństwa między obu zbrodniczymi systemami. A przy tym Bolesta jest świetnym obserwatorem: to realista, dążący do prawdy w opisie świata. Znakomicie, przenikliwie portretuje towarzyszy swej niedoli, bez zbędnego patosu opisuje ich martyrologię, uświadamia, iż komuniści bardzo świadomie skazywali na „zgnojenie” narodowe elity.

Pentalogia Krasińskiego jest powieścią autobiograficzną, bo wyraźne są podobieństwa biografii Bolesty i autora. Ale jednocześnie ta osobliwa powieść rzeka staje się coraz wyraźniej panoramicznym obrazem epoki PRL-u, a po trosze również powieścią obyczajową, pamfletem, studium psychologicznym ... Nawiązuje do konwencji realistycznej, a nawet naturalistycznej, posiłkuje się wspomnieniem, ale też sięga do konwencji reporterskiej, wykorzystuje autentyczne dokumenty, chwilami rozpadając się na - pozornie - luźne epizody o nowelistycznej konstrukcji.

Jeden z takich epizodów poświęcony jest Romkowi Strzałkowskiemu, a szerzej: wydarzeniom poznańskiego Czarnego Czwartku. Warto temu fragmentowi pentalogii przyjrzeć się bliżej, gdyż należy on - jak się wydaje - do ważniejszych miejsc w cyklu,

1 Jerzy Jarzębski widział w powieściach Krasińskiego charakterystyczny przykład „obrazu PRL w wersji martyrologicznej”, a więc takiej, w której „PRL jest przede wszystkim miejscem męki prawdziwych patriotów”, co jest trafne w odniesieniu do dwu pierwszych, więziennych tomów cyklu, potem rzecz się już komplikuje, martyrologia raz po raz ustępuje codzienności i banalności życia w komunistycznej Polsce [zob. Jarzębski 2016: 126; Burek 2011]. 
a jednocześnie wzbogaca stosunkowo skromną, zwłaszcza po roku 1989, literaturę dotyczącą poznańskiego Czerwca [Maciejewski 1988; Sterna-Wachowiak 1995].

2.

Wspomniany epizod znajdziemy w trzecim tomie cyklu, a więc w Niemocy, w rozdziale zamykającym tę powieść i noszącym taki sam tytul jak całość. To „wygłosowe” miejsce historii Romka Strzałkowskiego sygnalizuje od razu, jak ważną pozycję przyznawał jej pisarz w porządku dzieła. Opowieść o Czarnym Czwartku i śmierci Strzałkowskiego zamyka bowiem, a więc i puentuje tę część cyklu, która opowiada o perypetiach Bolesty po uwolnieniu z więzienia i jego pierwszych próbach odnalezienia się w kompletnie mu nieznanej rzeczywistości PRL-u. Odnalezienia w sensie nie tylko życiowym, ale też - że się tak wyrażę - poznawczym. Czym jest ta nowa Polska, co ją różni od świata więziennego - to pytania, które cały czas zadaje Bolesta, a odpowiedzią jest poniekąd zamykający powieść rozdział o śmierci Romka.

Warto jednak od razu podkreślić, że o Czarnym Czwartku i śmierci Strzałkowskiego Bolesta i czytelnicy Niemocy dowiadują się wcześniej, w czwartym rozdziale powieści, zatytułowanym Odwilż. Krasiński konfrontuje tu ze sobą dwa spojrzenia na wydarzenia 28 czerwca 1956 r.: komunistów i ich ofiary.

Najpierw pojawia się perspektywa komunistów. To od nich Bolesta uzyskuje informacje o „wypadkach” poznańskich. Znajduje się wówczas zresztą w specyficznej sytuacji: jest świeżo po debiucie literackim w „Po Prostu” i w zakopiańskim sanatorium leczy się z nabytej w więzieniu gruźlicy. Otoczony jest przez grono działaczy i działaczek komunistycznych, z jedną z nich, z towarzyszką Jolą z Poznania, nawiązuje nawet romans. I właśnie do tej spokojnej PRL-owskiej „czarodziejskiej góry” dociera wiadomość o strzałach w Poznaniu. Do wspomnianej Joli dzwoni mąż, lokalny działacz partyjny, który na gorąco relacjonuje jej, co się dzieje w mieście, a w pewnym momencie pozwala żonie (i otaczającym ją kuracjuszom) wysłuchać w słuchawce dźwięków strzałów rozlegających się na poznańskich ulicach. 
Krasiński pokazuje dwie zasadniczo odmienne reakcje na tę relację. W komunistycznych działaczach budzi ona zdenerwowanie, przerażenie, niepokój, wreszcie gniew. „Męty zdobyły broń i oblegają budynek [UB - M.U.]” [Krasiński 2006: 90]² - mówi Jola i pyta męża: „Dlaczego rząd nie pośle wam czołgów?! [...] Są przecież samoloty” [91]. Ona i jej koledzy określają wydarzenia w Poznaniu mianem kontrrewolucji i stwierdzają: „Hydra reakcji podnosi łeb i nie ma kto jej uciąć” [91].

Inaczej Bolesta. Wieści z Poznania budzą w nim „błysk niespodzianie rozbudzonych nadziei i gorycz niewiary” [90]. Dźwięk usłyszanych w słuchawce strzałów od razu kojarzy mu się z „,dobrze znanym z Powstania jazgotem karabinu maszynowego” [91]. Nie wierzy w to, co mówią o czwartkowych zajściach komuniści. „Zbyt dobrze znał ten obelżywy język propagandy, by nie wiedzieć, kto naprawdę mógł się kryć pod tą ubecką zniewagą. Jeśli ktoś oblegał bezpiekę, to z pewnością nie męty" [90]. Bolesta nie wierzy też w wersję o kontrrewolucji, widzi w Powstaniu „jakiś desperacki akt ostatecznego sprzeciwu doprowadzonych do rozpaczy ludzi” [91]. Ale nie zdobywa się na odwagę, aby przeciwstawić się Joli i jej towarzyszom. Jest sam, obawia się, że jego protest „uznano by za ujmowanie się za strzelającymi i zakrzyczano by go jako rzecznika zbrodni” [91-92]. Tęskni za spokojem, a zarazem wie, że „imperia zawsze potrafily karać wszelkie bunty z bezwzględnością i okrucieństwem, a jego kraj nie był wszakże wolny" [92].

Podobnie Bolesta reaguje na sławne przemówienie Cyrankiewicza. Raz tylko pozwoli sobie na wyrażenie krótkiego, sarkastycznego komentarza, ale umilknie „pod groźbą syków i gniewnych spojrzeń" [96] innych słuchaczy. Tylko w myśli nazwie więc premiera „czerwonym folksdojczem” [96] i „ponurym błaznem” [97], a całe przemówienie „chytrą sztuczką” [96]. Czarny Czwartek to dlań kolejna „komunistyczna zbrodnia usprawiedliwiana koniecznością reakcji na knowania zachodnich imperialistów" [95-96], ale też „powstanie” [97] i „kolejna klęska narodowa” [97]. Dlatego po wysłuchaniu Cyrankiewicza jest „wstrząśnięty, zgnębiony jak

2 Wszystkie cytaty z omawianej powieści pochodzą z wydania Krasiński 2006, dalej podaję jedynie numery stron w nawiasach kwadratowych. 
niegdyś po utracie ostatniej nadziei, po upadku Paryża [w 1940 r. M.U.]” [98].

Chwilę potem dowiaduje się od coraz bardziej wątpiącej w oficjalną wersję Joli, że w Poznaniu zginął ,jakiś chłopiec”, który „nosił im sztandar, a oni go zabili” [99]. Z rozmowy z kochanką dowiaduje się kolejnych szczególów o Romku Strzałkowskim, o jego wieku, o tym, że był uczniem szkoły muzycznej i że jakoby zastrzelili go demonstranci. Obraz trzynastoletniego chłopca „z robotniczym sztandarem”, nie pogrzebanego, porzuconego „gdzieś w kącie kostnicy" będzie go odtąd nawiedzał w wyobraźni [101]. W jednym z koszmarów sennych zobaczy go „z krwawą plamą na piersi, z podniesionymi do góry rączkami” [108], w innym „malec”, wciąż z podniesionymi do góry rękoma, rozżalony skarży się, iż podano nieprawdziwą wersję jego śmierci:

Zabrana do grobu straszliwa krzywda wyzierała mu z martwych oczu. Stojąc na jakiejś stromiźnie, na nieskończenie umykających wzwyż szczeblach drabiny czy na górskim szlaku, wciąż nie opuszczając podniesionych rąk, spoglądał na Szymona z bezgranicznym wyrzutem. $\mathrm{Z}$ martwych jego oczu wyzierał żal umarłego do śniącego ten sen. Obarczał go winą za to, że ten żył, że tylekroć wymknął się śmierci, gdy on, prawie dziecko, musiał umrzeć przy pierwszym z nią spotkaniu. [109]

Znamienne, że dla Bolesty równie dotkliwe jak śmierć niewinnego chłopca jest kłamstwo na temat jej okoliczności. Utwierdza się w przekonaniu, że „ten system nie umie obyć się bez zbrodni” [107], że charakterystyczna jest dlań „nagminna praktyka” tworzenia „przewrotnych wersji” popełnionych w imię komunizmu zbrodni [109].

Bolesta w rozmowie z przybyłym do Zakopanego Miszą Prociuchem, mężem kochanki, sprzeciwi się rządowej wersji zabójstwa Romka i samego Czarnego Czwartku, który nazywa konsekwentnie powstaniem. Odwołuje się do swych więziennych doświadczeń, przecież „[... ] doskonale zna metody bezpieki i wie, jak umniejszać swe zbrodnie przez oszkalowanie ofiary" [111]. 
Mimowolnie podsłuchane słowa Miszy, który chce złożyć kłamliwe zeznanie, jakoby Romek okradał stoiska targowe w czasie zamieszek, „oblazły Szymona jak robactwo” [135], a samego Prociucha Bolesta nazwie w myślach „cmentarnym ptasiorem” [135]. Odraza miesza się ze wstrząsem - budzi je w nim „zuchwalstwo negliżującego się przed nim zła” [135].

Z całej dyskusji wypłynie zresztą dla Bolesty jeszcze jedna lekcja, którą uświadomi mu przerażona Jola: „[... ] wy tam w więziennej celi mówiliście, co tylko wam się podoba. Ale tu nie więzienie, tu każdy wie, co wolno powiedzieć” [114].

3.

Mówiąc o Strzałkowskim w zakończeniu Niemocy, Krasiński posługuje się klasycznym chwytem opowiadania w opowiadaniu. Oto w początku lat 6o. xx w. Bolesta pracuje już w redakcji warszawskiego tygodnika literackiego i zjawia się u niego młody człowiek. Przynosi mu rękopis opowiadania Śmierć Romka, prosząc o pilną lekturę i szybką odpowiedź co do możliwości druku, w które nie bardzo wierzy. Mówi zmieszanemu Boleście: „Im bliżej jest się prawdy, tym mniejsze ma się szanse na druk" [497].

W samym opowiadaniu znowuż ważne jest ono samo, jak i okoliczności towarzyszące jego lekturze. Otóż Bolesta zabiera maszynopis do domu, ale wcześniej - wracając z pogrzebu towarzysza więziennej niedoli, dręczony silną gorączką - będzie w warszawskiej kawiarni rozmawiał z tajemniczym nieznajomym na temat sensu literatury i swego pisarstwa. Szymon swe zadanie widzi w „przemycaniu pamięci” o ofiarach zbrodni [503]. Gdy nieznajomy szydzi, iż pamięć to „chora narośl na naskórku plechy wydarzeń, mazgajstwo niewolników” [504] i że nie powinno „oglądać się za truchłem przeszłości” [505], oburzony Bolesta wylicza zbrodnie, których był świadkiem. Mówi między innymi o żydowskich dzieciach idących do gazu: „to jest pięć minut takiej zbrodni, że pamięć o niej powinna budzić świat z każdym wschodem słońca” [505].

Takim „gestem” pamięci jest również Śmierć Romka, obszerna, zajmująca ponad trzydzieści stron historia ostatniego dnia życia 
tytułowego bohatera, którego oczyma oglądamy wydarzenia Czarnego Czwartku, począwszy od wczesnych godzin porannych aż do chwili, gdy pada strzał. Krasiński, a ściślej rzecz ujmując: narrator opowiadania, pokazuje jednocześnie, jak rozwijały się wypadki tamtego dnia i co działo się z Romkiem. Ważne jest tu ukazanie nie tylko okoliczności jego śmierci i wydarzeń, które do niej doprowadziły, ale też wewnętrznej ewolucji samego Strzałkowskiego. Od porannego uczucia zawodu, że wbrew oczekiwaniu wciąż kursują poranne tramwaje, aż po końcowy „niemiłosierny ból” [536] towarzyszący jego śmierci. Narracyjna „kamera” oscyluje więc między obrazami zrewoltowanej poznańskiej ulicy i opisami wewnętrznych doznań Romka. Reportaż staje się psychologicznym portretem, a Strzałkowski jest wnikliwym „reporterem”, szczególowo rejestrującym kolejne etapy robotniczego pochodu, wygląd jego uczestników, ich reakcje, okrzyki i transparenty, a jednocześnie przechodzi wewnętrzną przemianę, a nawet rodzaj duchowej inicjacji - ze świadka staje się coraz bardziej świadomym i coraz bardziej dumnym uczestnikiem wydarzeń, z dziecka zmienia się w „świadomego rzeczy mężczyznę” [530].

Początkowo wydarzenia, w których uczestniczy, traktuje jako zabawę, klaszcze w dłonie „jak w cyrku” [510], a słysząc Rotę, zaczyna dyrygować [510]. Potem potężniejący pochód porównuje do „ogromnej ludzkiej rzeki” [513], „krucjaty” [513], „konduktu trędowatych” [514], by wreszcie uświadomić sobie z „trwożną dumą” [515], iż uczestniczy w „prawdziwym powstaniu” [526]. Ale niedługo potem - po rozmowie z, najpewniej, prowokatorem - Romek z przerażeniem odkryje, że „w tym tłumie, który się wykrwawiał, pełno było ubeków” [529], i nazwie wydarzenia, w których uczestniczy, „szatańskim tańcem” [529] oraz „grą mającą przynieść złagodzenie tyranii despotyzmu w drodze zamiany jej na dyktaturę" [529].

Krasiński podkreśla więc początkowo dziecinność Romka, jego wrażliwość, a potem, w miarę jego szybkiego dojrzewania, intelektualną przenikliwość:

Popatrzył na tych, co szli obok niego. Ludzie o twarzach zwiędłych liści. Młodzi, a jakby już starzy. Z gorączką w oczach, jaką 
miewał jego tata, gdy mówił o potajemnych mordach dokonanych na posłach przeciw komunistom partii. I jak nienawistnie spoglądali w okna tej mordowni. [... Romek czul, jak z każdą chwilą w burzową chmurę zmienia się dusza ludu. [523]

Gdy pod wpływem narastających wątpliwości, „ledwie uświadamianego przeczucia zła” [531], Romek postanawia wrócić do domu, zostaje schwytany przez ubeków. Krasiński, przedstawiając ostatnie chwile Strzałkowskiego, opowiada się za tą z wersji, która mówi, iż został on zamordowany przez któregoś z ubeków strzałem w plecy w momencie, gdy stał na schodach w cywilnej części budynku zamieszkanej przez rodziny ubeków, z podniesionymi do góry rękoma, zupełnie nie spodziewając się śmierci³. Bezradność i strach Romka narrator zderza z agresywnością ubeków, którzy przypominają zwierzęta. Kilkakrotnie wraca obraz dziecka z uniesionymi do góry rękoma, zabijanego przez umundurowanych mężczyzn, nasuwający zresztą skojarzenia ze znanym zdjęciem żydowskiego chłopca stojącego z podniesionymi do góry rękoma w warszawskim getcie w roku $1943^{4}$.

Z kolei jeden z dorosłych „miał w sobie coś z pająka” [531], twarze innych były „spięte, czujne niczym pyski psów przed polowaniem” [532]. Sam Romek czuje się „jak zwierzę w potrzasku” [532], jego prześladowcy nazywają go nie tylko „chorążym tego motłochu” [534], ale i „reakcyjnym szczenięciem” [534]. Z drugiej strony zaskoczony Romek słyszy odgłosy bawiących się w swoich mieszkaniach dzieci ubeków. Zło, którego jest świadkiem i w końcu ofiarą, oddzielone jest cienką granicą od zwyczajności.

Nie do końca wiemy, dlaczego Romek ginie - czy dlatego, że uczestniczył w pochodzie, czy też dlatego, że zobaczył zastrzeloną przez ubeków dziewczynę, która też brała udział w manifestacji. Śmierć Romka nie jest jednak heroiczna. Autor opowiadania raczej podkreśla to, iż spada ona na chłopca niespodziewanie, jest śmiercią zdradziecką, a przez to tym bardziej okrutną. czyk, Maldis 2006: 13-46; Jakimek-Zapart, Zapart 2016; Strzatkowski Roman 2016]. 
Pod wpływem lektury całości opowiadania, którego częścią końcową jest „autentyk”, pismo ojca zamordowanego, Jana Strzałkowskiego, do prokuratora generalnego, dotyczące manipulowania prawdą o śmierci syna, w Boleście budzą się litość i gniew, ale też pamięć „dziecięcej śmierci [...] z całym swym tragizmem” [536], „obiektu najohydniejszych manipulacji poznańskiej bezpieki, szarganej od swego pierwszego tchnienia, szkalowanej przez fałszywych świadków, bezczeszczonej, namaszczanej stekiem prasowych oszczerstw" [536].

Ale jego redakcyjni współpracownicy odrzucą opowiadanie jako sławiące „żądny zemsty motłoch kontrrewolucji” [542]. Bolesta decyzję tę przyjmie z ulgą, bo zdejmie ona zeń „ciężar odpowiedzialności” [545].

Pamięć o Czerwcu, skomplikowana prawda o Czarnym Czwartku, których symbolem jest Romek i jego śmierć, okazują się niewygodne dla wszystkich, a zarazem niemożliwe do ujawnienia w kraju. Śmierć Romka zostanie wprawdzie ogłoszona przez autora na emigracji, ale nikt nawet nie dostrzeże tego utworu.

4 .

Warto zwrócić jeszcze uwagę na miejsce epizodu o Romku w całej pentalogii Krasińskiego. Wprawdzie sam Strzałkowski już nie powróci na karty cyklu, ale w poprzednich i kolejnych tomach będą się pojawiać nieco podobne do niego postaci, takie jak więzień Auschwitz Genia Worobiow w Przed agonią. Niemal każdy z tomów pięcioksięgu kończy się podobną, żałobną puentą, opisującą śmierć ofiary totalizmu. W tych tragicznych losach zdaje się przeglądać sam Bolesta, w nich też zdaje się on widzieć istotę totalizmów, z ich okrucieństwem i bezwzględnością. Dostrzega w nich nić spajającą polską historię, bo - jak powie Bolesta - „wielkich ludzi mojego narodu zawsze czeka albo szubienica, albo zdradziecka kula” [Krasiński 2015: 46o]. Inna rzecz, iż wielkość Strzałkowskiego nie jest natrętnie podkreślana. „Mały chorąży” [528] bardziej ciekawi Bolestę jako niewinne, wrażliwe i bezbronne dziecko, uwikłane w nie do końca dlań zrozumiałą historię, której sens dostrzega, ale przecież nie zawsze. 
Stąd może ambiwalentny powrót Bolesty do Poznania w ostatnim tomie cyklu, a więc w Przełomie, a ściślej w rozdziale jedenastym tej powieści. Jest 24 czerwca roku 1994 i główny bohater pentalogii przybywa na uroczystość „Dni Radia Wolna Europa w Poznaniu”. Jest jednym z uczestników panelu, w którym opowiada o swoich doświadczeniach słuchacza i zarazem autora monachijskiej rozgłośni. Słucha też przemówienia Lecha Wałęsy, który wspomina wydarzenia sprzed trzydziestu ośmiu lat. Reagując na nieścisłość w tym przemówieniu, Bolesta pokaże emocje, jakie wciąż w nim budzi Czarny Czwartek, i tak istotną dlań troskę o to, aby zachować o tamtym dniu jak najwierniejszą pamięć:

Piękne przemówienie! Lecz Szymona aż uniosło na krześle i omal nie wykrzyknąl: „Panie Prezydencie, robotnicy nie wyszli wtedy z Zakładów Cegielskiego, oni wyszli z Zakładów im. Lenina! Zapewniam pana, że Cegielski nie wysłałby na nich czołgów!” Bo jakże to, dyszał wzburzony, bohater Sierpnia, jego bohater, już u progu wolności zaciemnia, mija się z historyczną prawdą?! [Krasiński 2015: 409]

Obserwując z kolei tłumy poznaniaków wiwatujące radośnie na cześć przybyłych z zagranicy redaktorów i autorów Radia Wolna Europa, Bolesta składa w myśli hołd tym pierwszym:

To oni, obywatele tego miasta, byli prawdziwymi bohaterami. To oni trzydzieści osiem lat temu wyszli z fabryki na miasto. To oni z okrzykiem: „Na pajęczynę, na pajęczynę!” - ruszyli na gmach ubezpieczalni społecznej, gdzie pod jej czcigodnymi skrzydłami pracowała zaciekle zagłuszarka. To oni wdarli się na dach i postrącali z niego maszty zagłuszające urządzenia. To ich kobiety, dziewczyny wskakiwały na czołgi. „Dokąd jedziesz, stalinowski pachołku?” i czołgista poddawał się krzyczącym o wolność rodaczkom. I to oni śpiewając Boże coś Polskę... nieśli na drzwiach, jak na marach, zabitych robotników, kolegów, choć byli i tacy, co na ten widok zaciągali okna. [Krasiński 2015: 411-412] 
Prawda o bohaterach Czarnego Czwartku wciąż więc nie jest znana i doceniana.

Zbigniew Herbert w rozmowie z Jackiem Trznadlem, opublikowanej w Hańbie domowej (1985), zauważył, że „jedyne prawdziwe robotnicze powstanie w Polsce, w Poznaniu, nie miało żadnego echa, [bo - M.U.] zaskoczyło intelektualistów” [Trznadel 1994: 189].

Po lekturze analizowanych fragmentów powieści Krasińskiego możemy domyślić się, z czego mogło wynikać to zaskoczenie, a potem strach pisania czy mówienia o Poznaniu. Krasiński ciekawie odtworzył ówczesne reakcje na wydarzenia Czarnego Czwartku, nadzieje jednych, lęki drugich. Poznański Czerwiec to dla bohatera powieści zderzenie $\mathrm{z}$ przemocą i złem, również z kłamstwem i manipulacją. W epizodzie opisującym śmierć Romka Krasiński dostrzegł symbol poznańskiego powstania, wpisał je w ciąg polskich powstań, stworzył wreszcie przejmujący, literacki akt oskarżenia wobec komunizmu.

\section{Bibliografia}

Burek Tomasz (2001), Ciernie i wawrzyny, w: tegoż, Dziennik

kwarantanny, Wydawnictwo Arcana, Kraków.

Burek Tomasz (2011), Wyjście na wolność (Janusz Krasiński), w: tegoż,

Niewybaczalne sentymenty, Iskry, Warszawa.

Heck Dorota (2008), Między racjami teoretyka a intencja autorską.

Nad tetralogia Janusza Krasińskiego, w: Wyobraźnia i pedanteria.

Prace ofiarowane prof. Wojciechowi Gtowali w 65. rocznicę urodzin, red. Maciej Adamski i in., Oficyna Wydawnicza ATUt -

Wrocławskie Wydawnictwo Oświatowe, Wrocław.

Jakimek-Zapart Elżbieta, Zapart Robert (2016), Roman Strzałkowski

[online], [dostęp: 3 września 2016], http://www.ipsb.nina.gov.pl/ index.php/a/roman-strzalkowski.

Jarzębski Jerzy (2016), PRL w narracjach, w: tegoż, Proza: wykroje i wzory, Universitas, Kraków.

Krasiński Janusz (2006), Niemoc, Wydawnictwo Arcana, Kraków. 
Krasiński Janusz (2015), Przełom, Wydawnictwo Arcana, Kraków. Łubczyk Grzegorz, Maldis Marek (2006), 13 lat. 13 minut. 13 év.13 perc, przeł. na język węgierski Erzsébet Szenyán, Péter Józsa, Rytm, Warszawa.

Maciejewski Janusz (1988), Poznański Czerwiec po 3 o latach, „Przegląd Katolicki”, nr 26, s. 4-5; nr 27, s. 4-5, 8.

Sterna-Wachowiak Sergiusz (1995), Symbol i rana: Czerwiec 1956 w poezji i prozie, „Kronika Miasta Poznania”, nr 4, s. 61-95.

Strzałkowski Roman (2016), [online], [dostęp: 2 września 2016], https://pl.wikipedia.org/wiki/Roman_Strzałł\%C582łkowski.

Trznadel Jacek (1994), Wypluć z siebie wszystko. Rozmowa ze Zbigniewem Herbertem, w: tegoż, Hańba domowa, Agencja Wydawnicza Morex, Warszawa.

Urbanowski Maciej (2007), „Kamieniem niemocy przywalona epopeja” („Przed agoniq” Janusza Krasińskiego), w: tegoż, Dezerterzy i żotnierze. Szkice o literaturze polskiej 1991-2006, Wydawnictwo Arcana, Kraków.

Weber Mark (2016), The „Warsaw Gehtto Boy” [online], [dostęp: 3 września 2016], http://www.ihr.org/jhr/v14/v14n2p-6_Weber.html.

Maciej Urbanowski

\section{„Śmierć Romka” (Poznań 1956 protests in prose by Janusz Krasiński)}

The article reconstructs and analyses the image of Poznan 1956 protests in the well known novel cycle by Janusz Krasiński. For the protagonist, Szymon Bolesta, the death of Romek Strzałkowski is particularly painful, an event extensively reconstructed in the conclusion of Niemoc, one of the novels. The execution of Romek and the propaganda lies about it, are for Bolesta the key examples of the criminal nature of the communist regime, and the Black Thursday he interprets as an unsuccessful national uprising.

Keywords: Janusz Krasiński; contemporary Polish prose; Roman Strzałkowski; communism; Uprising in Poznań in 1956.

Maciej Urbanowski - historyk literatury polskiej xx w., krytyk literacki, edytor, kierownik Katedry Krytyki Współczesnej na Wydziale Polonistyki uJ, ostatnio opublikował Romans z Polską. Szkice o literaturze wspótczesnej (2014) oraz Prawa stronę literatury polskiej. Szkice i portrety (2015). 